УДК: 364.273

\title{
ADAPTATION AND SOCIALIZATION OF SOCIAL ORPHANS IN KYRGYZSTAN
}

\author{
R.B. Salmorbekova \\ (iD) https://orcid.org/0000-0002-7580-9694 \\ Director of NGO «SOTSANTRO», Bishkek, Kyrgyz Republic, \\ e-mail:r.salmorbekova@mail.ru,
}

\section{K. Karimova \\ Osh State University, Osh, Kyrgyz Republic, e-mail: kunduz.karimova.70@mail.ru}

\section{DOI:10.14258/ssi(2020)3-03}

The article presents analyses of the main causes of the increase in the number of social orphans in Kyrgyzstan. Based on the materials of a sociological research, conducted by the initiative of the Ministry of Social Development of the Kyrgyz Republic in 2016, it was revealed that $99.5 \%$ of social orphans live in orphanages. For a child who grew up without a family, the agents of socialization are: zhamaat (community), peers and educators of orphanages. Today, as never before, social orphans need in orphanages and boarding schools. Due to the lack of contacts with parents, many social orphans have an incorrect understanding of different social roles. The lack of such contacts leads to difficulties in socialization and adaptation in society. Besides, inmates of orphanages have changes in social relations, a weak self-confidence, a decrease in targeting, and etc.

Keywords: adaptation, upbringing, maladjustment, social orphans, socialization, social institutions, family 


\section{АДАПТАЦИЯ И СОЦИАЛИЗАЦИЯ СОЦИАЛЬНЫХ СИРОТ В КЫРГЫЗСТАНЕ \\ Р.Б. Салморбекова \\ https://orcid.org/0000-0002-7580-9694, \\ ОО «СОЦАНТРО», Бишкек, Кьргызская Республика, e-mail: r.salmorbekova@mail.ru}

\section{К. Каримова \\ Оиский государственньй университет, Ои, Кььрьззкая Республика, e-mail: kunduz.karimova.70@mail.ru}

В статье представлен анализ основных причин увеличения количества социальных сирот в Кыргызстане. На материалах проведенного по инициативе Министерства социального развития Кыргызской Республики социологического исследования (2016 г.) было выявлено, что в детских домах 99,5\% проживающих детей являются социальными сиротами. Для ребенка, выросшего без семьи, агентами социализации являются: жамаат (община), сверстники и воспитатели детских домов. Сегодня как никогда для социальных сирот необходимы детские дома и интернаты. У многих социальных сирот в связи с нехваткой контактов с родителями и другими значимыми взрослыми возникают проблемы с пониманием и выполнением социальных ролей. Нехватка таких контактов приводит к трудностям в социализации и адаптации в обществе. Вместе с этим у воспитанников детских домов возникают изменения в социальных отношениях, слабая вера в себя, снижение целенаправленности и т. д.

Ключевые слова: адаптация, воспитание, дезадаптация, социальные сироты, социализация, социальные институты, семья

\section{Introduction}

Difficult socio-economic conditions cause for the problem of social orphanhood. Wars, epidemics, poverty and other causes lead to the death of parents. As is well known, the orphanhood is a social phenomenon concerning lives of children without parents. Until the nineteenth and twentieth centuries orphans were children who lost their parents because of their death manly, and they always evoked sympathy and a desire to help among all good people and a sense of duty and duty of the state. However, in modern conditions, orphanhood is generated not only by the death of parents, but by societal crisis also. Crisis and severe socio-economic upheavals affected not only the financial situation of people, but their worldview to some extent. In times of crisis, original traditions and norms of the family are broken down by drunkenness, drug addiction, and the parents' deliberate lifestyle that led them to calmly abandon their children. So, new types of orphanhood called «social orphans» appeared. The crisis of the family institute destroys children lives. Family is the main social factor for a child. Together with the family, the child develops, 
that is, he/she learns the world with its traditions and behavior and learns how to exchange thoughts. The family is the first agent of socialization of a person, his or her familiarization with norms and principles of society.

The urgency of the problem of social orphans in Kyrgyzstan. The modern youth is experiencing three main issues: acceleration processes, a sharp change in living conditions, and early sexual debuts. These three criteria cause for the emergence and growth of the number of social orphans. According to the statistics committee, there is an increase in the number of pregnant among juvenile girls and in the number of births among women of 13-17 years, from year to year (table 1).

Table 1

Number of births among women aged 13-17 years

\begin{tabular}{c|c|c} 
№ & Years & Number of births \\
\hline 1 & 2013 & 1320 \\
\hline 2 & 2014 & 1235 \\
\hline 3 & 2015 & 896 \\
\hline 4 & 2016 & 734 \\
\hline 5 & 2017 & 455 \\
\multicolumn{2}{l}{ Source: Women and men of the Kyrgyz Republic: 2013-2017. Bishkek, 2018. P. 114 }
\end{tabular}

Refusal of newborn children is now regarded as a common social phenomenon. In maternal behavior, socio-economic factors play an important role. The change in family and marriage relations among youth is expressed through the freedom of relationship and the spread of civic marriages. The lack of parental support and state control prevail over economic benefits. In Kyrgyzstan, unregistered marriages made only according to the Muslim rituals, complying with the Sharia but not with the legal norms of the state, have become popular. In $45 \%$ of cases, newborns with both parents are registered only at the request of their mothers and, most likely, these children will be raised in a family without a father. By the end of 2017 there were more than 91 thousand socially disadvantaged, dysfunctional, difficult families with about 292 thousand children in Kyrgyzstan ${ }^{1 .}$

Refusal of newborn children is now regarded as a common social phenomenon. In maternal behavior, socio-economic factors play an important role. The change in family and marriage relations among youth is expressed through the freedom of relationship and the spread of civic marriages. The lack of parental support and state control prevail over economic benefits. In Kyrgyzstan, unregistered marriages made only according to the Muslim rituals, complying with the Sharia but not with the legal norms of the state, have become popular. In $45 \%$ of cases, newborns with both parents are registered only at the request of their mothers and, most likely, these children will be raised in a family without

\footnotetext{
${ }^{1}$ National Statistical Committee of the Kyrgyz Republic. Statistical overview dedicated to the International Children's Day. URL: http://www.stat.kg/ru/news/statisticheskij-obzor-k-mezhdunarodnomu-dnyu-zashitydetej/
} 
a father. By the end of 2017 there were more than 91 thousand socially disadvantaged, dysfunctional, difficult families with about 292 thousand children in Kyrgyzstan ${ }^{1}$.

According to the Ministry of Social Development of the Kyrgyz Republic, 154 children's organizations and institutions provide social services to children. Among them 71 are public; 65 - private; 15 - municipal; 2 - philanthropic. About $70-80 \%$ of social orphans constitute approximately $70-80 \%$ of children in orphanages. Having living parents, children are in boarding schools and often have disabilities; rather often their parents are migrant workers or prisoners.

Almost $80 \%$ of migrants from Kyrgyzstan work in Russia and 15\% in Kazakhstan, and the most part of migrants originated from the southern regions of Kyrgyzstan. A trend of abandonment of a newborn child by migrants from Kyrgyzstan has become common. Despite this, the State is committed to protecting its citizens. Since 2011, the Ministry of Social Development of the Kyrgyz Republic have returned 85 children who were refused by migrants (mothers) to their homeland from the Russian Federation. The majority of them were taken out from Moscow, Krasnoyarsk, and Novosibirsk. According to the ministry, only 10 children were returned to their families, according to a court decision 50 children were adopted, the rest 25 children were placed in the orphanage 2 .

The general category of orphans includes children whose parents were deprived of parental rights because of deviant behavior in society (social orphans). Social orphanhood in Kyrgyzstan remains an urgent problem for many researchers, especially now, when negative conditions are activated in the world community: crime, extremism, and terrorism, as well as drug and alcohol abuse. Since the majority of social orphans were born precisely in such conditions, the problem of their re-socialization is of particular importance and very vitally serious relevance for the future Kyrgyz society, where more than a half of the populations are the young people and the birth rate is quite high. In modern conditions, sexual relations are not directly related to childbearing: the full legalization of preventive measures, the lifting of prohibitions on timely termination of pregnancy can be considered as one of the means of preventing the growth in the number of social orphans. Children need in social education. Therefore, a comprehensive scientific study of this issue is an urgent task. The problems of children in society are significantly linked with the development of the human factor: social living standard of development, protection of rights, the tasks of social education in the process of socialization, street children, social orphans especially, and the social adaptation of children in orphanages are the sociocultural mission of a civilized society.

All of the above-mentioned indicates the relevance of not only the scientific and theoretical study of this problem but the practical side is no less important: the problem of re-socialization of social orphans, their adaptation to modern needs and requirements of the Kyrgyz society in the work of orphanages, the development of innovative means and methods in this direction are required.

\footnotetext{
${ }^{1}$ National Statistical Committee of the Kyrgyz Republic. Statistical overview dedicated to the International Children's Day. URL: http://www.stat.kg/ru/news/statisticheskij-obzor-k-mezhdunarodnomu-dnyu-zashitydetej/

2 The official site of the Ministry of labor and social development of the Kyrgyz Republic. URL: http://www. mlsp.gov.kg/?q=ru/doosu
} 
Among the works of foreign sociologists, the paradigm of the problem of social adaptation of orphans is represented by the concepts of anomie, deviation, and social mobility. They make it possible to identify the causes of social orphanage and the possibility of adaptation of children without parental care in a transforming society.

Some aspects of social orphanhood were revealed by the following authors: A.D. Stog, A.I. Volkova (Trostanetskaya, 2004: 3-8). Contemporary scholars analyze contemporary problems of orphans basing on historical experience: works by A.M. Nechaev, V.G. Bobrovnikov, L.V. Badya, O.V. Gorshkova (Furmanov, 1999: 160).

In the late 1980s and early 1990s, the problem of children without parents acquired particular importance in science and social practice. The category of «social orphanhood» was accepted into scientific circulation as a result of theoretical and methodological research, that enriched the understanding of the phenomenon of childhood. Studies about education in orphanages have been ongoing for a long time.

Proceedings of A.S. Makarenko (1981), N.K. Krupskaya (1959), V.A. Sukhomlinsky (1982) have determined that the problems of raising children in institutions for orphans are of great importance for the study of both practical and theoretical problems of raising children in such institutions. Other authors like L.I. Bozhevich, I.V. Dubrovina, M.I. Lisina, A.G. Ruzsko, A.M. Prikhozhan, N.N. Tolstoy investigated and described negative results of raising children in the state institutions. In the character of children who have grown up without a family, there are specific features in behavior; like other ordinary children. We cannot divide them into good and bad — simply because they are unusual (Shulga, 2005; Prikhozhan, 2007).

Works by A.M. Prikhozhan and N.N. The Tolstoy suggested answers about peculiarities of the perception of education in orphanages: how they will find their place in society, how the image of the personal self appears, what kind of relationships leads to the Self, and etc. In these conditions, the following factors affect the development of self-consciousness:

- the quick change of heads of institutions leads to the interruption of established relations and the assimilation of experience, that negatively effects on the process of education, generally;

- the pedagogical point of view of adults supposes to treat the child as an object of support, education and learning without distinction between positions of adults in the family;

- the lack of emotional relationships with adults and the specificity of group relationships with peers resulted in making a child to be unaware of his/her Self and self-misunderstanding.

- the strict regulation of the child's behavior does not allow the choice and formation of a sense of responsibility (Prikhozhan, 2007).

The system of the current upbringing of orphans has not reached a high level and is not ready to solve the problems of social adaptation of orphans, cannot psychologically prepare every child for difficult life circumstances.

Social rehabilitation is a comprehensive work with a child, restoration of destroyed social ties and work responsibilities; besides, it is the replenishment of life spheres, participation of non-governmental organizations, and institutions providing inalienable assistance to the child. 


\section{Research methodology}

The orphanage is a state social institution for a child, partially replacing the family. Considering the family and answering the questions about social functions it performs, we determine how the orphanage should work. Sociologist A. Kharchev defines the following social functions of the family:

- reproductive - the biological reproduction of the population in the social plan, the satisfaction of the need for children in the personal plan;

- educational - socialization of the young generation, maintaining the cultural reproduction of society;

- household - maintaining the physical health of members of the community, caring for children and elderly family members;

- economic - support for juveniles and disabled family members;

- primary social control - responsibility and obligations concerning spouses, parents and children;

- spiritual communication - the development of the personality of family members, spiritual mutual enrichment;

- social status - the presentation of a certain social status to family members; reproduction of the social structure of society;

- leisure - organization of rational leisure, mutual enrichment of interests;

- emotional - receiving psychological protection, emotional support (Harchev, 1979).

We presumed that orphanages with family functions should teach children social life i.e. to perform these social adaptation functions.

In 2016, with the support of the Ministry of Social Development of the Kyrgyz Republic, a sociological study was conducted in partnership with the public association SOTSANTRO. The purpose of the study was to identify the main problems of the adaptation process of social orphans in orphanages. The survey was conducted in the following institutions: boarding school No. 11 named after V. Tereshkova in Osh, boarding school for orphans and children without parental care named after M. Razzakova in Uzgen, boarding school № 13 named after I. Abdyrakhmanova in the city of Kyzyl-Kya, the Batken Oblast, the military Antonovka orphanage in the Chui region, the NGO «Movement Forward», the PF «Bright Way» and the children's home "Altyn uya» in Bishkek. The survey was attended by pupils of orphanages including social orphans, the sample size constituted 596 persons. The survey involved respondents aged 9 to 17 years, $40.3 \%$ were girls and $59.7 \%$ were boys. Besides, interviews with 48 experts (representatives of NGOs, employees of boarding schools and experts dealing with children's problems, etc.) were conducted.

\section{Main research results}

The orphanage for pupils is a temporary place of stay. After graduation, pupils plunge into independent life, and the success of their future life will depend on how the orphanage prepared its graduates for this life.

Social orphans graduating from orphanages are people who were in full state support until a certain time. But the state cannot solve all further problems. This requires 
the support of the entire population of Kyrgyzstan. There is a need not only in financial help, but also in moral and psychological ones.

Social orphans are children whose parents refused to educate, protect their rights and interests, and also children without parental care by law or other reasons. These are children whose parents are deprived of parental rights as a result of deviant behavior in society.

Increase in orientations on material values has led to devaluation of moral virtues and the crisis of the institution of the family which has undergone a radical change. According to experts, the reasons for the emergence of social orphans include addiction in $20 \%$ of cases, migration processes $-18 \%$, divorces $-14 \%$, unemployment $-12 \%$, low economic development of the country $-10 \%$, and the birth of children out of wedlock, financial situation of the family, poverty, early pregnancy, etc.

The phenomenon of social orphanhood in the minds of the Kyrgyz society is associated with common complex of reasons: political, social, medical, psychological and others. Typical life situations when children become social orphans are as follows:

- Parents (mainly mothers) consciously refuse a child, in most cases they leave the newborns in hospital. The abandonment of a child from a legal point of view is carried out in the form of an official legal act, legal documents are prepared. If within three months the parents change their mind, the child returns to the family.

- Parents, usually alcoholics with incorrect lifestyle from poor families, are forced to leave their children. Deprivation of parental rights is a legal act, a legal document and is proclaimed by a court decision.

Children living in orphanages experience serous changes in the psychological state. According to children's stories, they often hide that they live in orphanages and attend regular school with other pupils.

The "adaptation" (from Latin adaptare) means the adaptation of a living organism to the conditions of life. There are several definitions for the «social adaptation» concept:

1.The process of adapting a person to various changes in the social sphere by social means.

2. Adoption by each member of the group of the norms and values of the dominant class, their implementation in the lifestyle of the group by using the mechanisms of social and state supervision.

3. The process of active adaptation of a person to the conditions of social sphere; individual and social group movements in the public sphere; the results of harmonization of relations between the social sphere and the subject.

4. To successfully move in a social environment, an individual needs to master the knowledge of psychological, social norms and values of this environment (Dictionary of Psychology, 1990).

Work carried out by specialists of orphanages with pupils in the process of social adaptation. A social educator plays a significant role in supporting and helping children. The mission of a social educator is to be a plenipotentiary representative and advocate of the interests of teenage graduates in the world of official affairs and relations in various social institutions, to be a professional and personal consultant for a child on a wide range of life and personal problems, to provide support and assistance in new situations and to promote independence to children. 
According to the results obtained, 30\% of experts believe that the upbringing of children without parental care in an orphanage family or in orphanages is very suitable, $24 \%$ of experts believe that such children should be given to orphanages for adoption, $16 \%$ of experts replied that orphans should be handed over to relatives, $6 \%$ of experts consider that they need help. First of all (28\% of answers), orphans need children's homes, secondly, children are left without parental care (20\%), thirdly, children of prisoners and children left unattended (16\%), fourth, children from single-parent families (8\%), and children whose parents are on long-term treatment (6\%). Experts also determined that upbringing in orphanages is carried out by national pedagogical methods only in $2.0 \%$, innovative methods $-4.9 \%$, individual work with children $-30.2 \%$, and in $62.9 \%$ of cases only common pedagogical methods were used.

The model of professional competence of the social educator of children living in the orphanage and graduates includes a block of knowledge and skills:

knowledge of social pedagogy, psychology, social psychology, law, economics;

communicative, reflective, organizational and other abilities;

possession of counseling, training, diagnostics of adaptation technologies.

To fulfill its professional role, a social educator should be guided by the characteristics of individual, group, and professional psychology in a broad sense, the conditions and specifics of the activities of subjects of social interaction, the features of the environment, the conditions and the specifics of the activities of various social institutions (Sataeva, 2004).

The main direction in the work of the teacher on social adaptation is the function of a «multifaceted consultant» and a «multifaceted mediator».

The main function of a social educator is the mediation between the pupil and the surrounding society. A social educator should have connections to protect the rights and interests of children (pupils) against the violation, to establish contacts between specialists - social welfare workers, assisting graduates, members of the Ministry of the Interior, and health and public organizations.

The difficulty of the problem of dependence, recognition of the socio-pedagogical environment can inhibit the attitude in the social environment. All this negatively affects the upbringing and causes for the addiction of the school and deviant behavior in many cases.

Usually, social orphanhood refers to situations when a child with living biological parents remains, for some reason, without education in society. In these cases parents are deprived of parental rights. Another category of social orphans is hidden orphans with living parents, when children live with their parents, but parents treat negatively each other. In such situations, children sometimes remain completely without material and moral care, so that they are no different from orphans. And this also requires the attention of the State and the public.

A social educator carries out special work with adolescents who grew up in orphanages in the process of their adaptation and disadaptation in society. For orphans and children left without parental care, a social educator is a source of social protection on the part of society and the sState. Also, the social educator for the pupil of the orphanage is the organizer in of the process of adaptation. The main objective of the educator's professional 
work is to introduce the concept of «A person must lead a decent lifestyle» into the consciousness of children.

Orphanages receive children who have experienced severe stress and children from a family with different psychological characteristics. Therefore, the process of education requires an individual approach not only to their physical but also to psycho-emotional development. Under these conditions, children separated from their family reject the state system. Besides, in the modern Kyrgyz society, the concept of violence in education is poorly developed, that creates difficulties for the psychological development of children. Some types of violence are the norm of upbringing. The lack of social assistance to the child in such a situation creates favorable conditions for the development of orphanhood. Orphaning reduces potential. For pupils leaving the orphanages, the role of an orphan, soaked in them, closes internal resources, and they cannot use them. In orphanages, in a difficult life conditions, the personal characteristics of children do not develop, therefore, in the process of socialization based on difficulties, psychological growth in children is hampered.

Types of punishments in orphanages. There are facts of the physical punishment of pupils; in two institutions psychological and emotional punishments were applied. In other institutions, various types and forms of physical punishment are used.

Besides the state upbringing, children have individual characteristics that decide their fate. Social disadaptation in various forms is a companion to children from orphanages. Orphans are a problem group not only from a psychological point of view, even if they come from good families. We can assume that all this is the beginning of the formation of a certain life position. By tradition, the first family gives all potentials: social status, upbringing, health, knowledge and other characteristics have no limitations and do not require explanation (Nazarova, 2001).

The main position of orphans is the taken level of development for themselves and from state institutions: mental and physical, as well as upbringing and knowledge. But there are reasons for punishment: $22 \%$ of respondents note that they were subjected to offenses, $78.0 \%$ did not violate the rules, almost all offenders claim that they are were rudely punished by educators. Because of this, $52.2 \%$ of children want to grow up earlier, $13.5 \%$ of children would like to grow up faster, $34.3 \%$ of children don't want to become adults at all. Being «adult» for $19.6 \%$ of children means «I want to do what I want», for $73.4 \%$ - «I will work, I want to have money», for 5.4\% — «tired of being dependent»; for $1.7 \%$ - «tired of the orphanage».

To the question «Have you run away from the lessons?» $26.1 \%$ of respondents answered that they always run away, 73.9\% — did not run away from school. For orphanage inmates running away from a lesson (35.9\%) is an offense, $40.8 \%$ - «bad behavior», $10.6 \%$ - see nothing wrong with that, $12.7 \%$ - know that it is not good to leave lessons, but still run away.

Special preventive, educational work with minors in orphanages is carried out. The next stage of preventive work is rehabilitation. The development of rehabilitation depends on understanding of preventive features. This is the attitude of minors to education, educators, work, health, psychological development, behavior, and self-expression. 
In the process of social adaptation, educators often encounter the following problems: $43.5 \%$ of respondents note the absence of adequate living conditions compliant with modern requirements in orphanages (almost all the orphanages covered in the study were built in the Soviet period, the year of construction - 30 years ago), $48.6 \%$ - the severe psychological state of orphans living in orphanages, $7.9 \%$ - an acute shortage of teachers experienced in the process of adaptation of orphans.

Priority areas for addressing the problems of social orphans. Answering the question: «In what areas is there a need to organize retraining courses for caregivers in orphanages?», $20.9 \%$ of experts noted the psychological direction, $7.0 \%$ - the legal, and $51.2 \%$ - all professional areas. Thus, there is a need for periodically organizing continuing education courses for specialists working in orphanages.

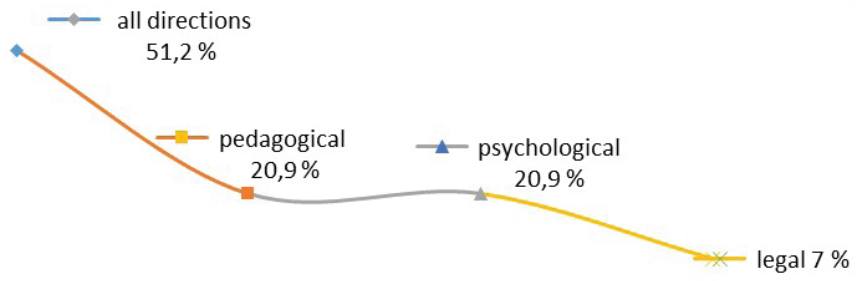

Figure 1 - The need in training courses for social educators working in Kyrgyz orphanages, \%.

For educators of orphanages, special training courses are required as well, taking into account that $25 \%$ of them do not have pedagogical experience and do not know the methods of working with psychologically retarded children. This situation is explained by low teachers' salaries (the monthly salaries of teachers are 9,000 soms or 8,529 rubles) which lead to the lack of motivation in work. Therefore, teachers of orphanages from time to time need to be trained in specially prepared courses.

According to our research, selected orphanages are home to:

- $26.9 \%$ of children from a dysfunctional family;

- $23.1 \%$ of children whose parents are divorced;

- $16.6 \%$ of children are orphans (absence of one parent);

- $16.1 \%$ of children who are parents in the Russian Federation;

- $9.7 \%$ of children from a large family;

- $6.0 \%$ of children of single mothers;

- $1.1 \%$ of children with disabilities;

- $0.5 \%$ orphan.

As can be seen from the above, among children in orphanages, $99.5 \%$ are of social orphans who are left without parental care. Today orphanages are not for orphans, but for social orphans. Preventive measures to reduce the number of social orphans should be taken into account in the state strategic development plan of the country. The state and society should take strict control of internal and external migration. It is necessary to 
develop the institution of the family and to conduct propaganda in the media to develop laws on mother and child.

\section{Conclusion}

To reduce the growth in the number of social orphans, it is necessary to organize work with young families through the media and public organizations, bringing to their consciousness that raising family implies efforts to preserve it, patiently endure all the inevitable material and spiritual difficulties along this path for the sake of a noble goal: raising healthy, good children without any deviations, inevitable in conditions of an orphan, life for the sake of their future family and the whole Kyrgyz society.

As a result of research, we identified and put forward the following levers and proposals to reduce the growth in the number of social orphans:

1. To reduce the growth of social orphans in orphanages in Kyrgyzstan, it is necessary to adopt strategic programs at the state level. External migrants, mothers with minor children should be prohibited from leaving the country. Increase responsibility in the adoption of children.

2. Inform the youth about the necessity to strengthen the family, implement them in the media and social networks. There is a need in to make extensive use of national pedagogical and innovative methods.

3. On the part of experienced social educators, to solve the problems of children in an orphanage, to overcome difficulties in the adaptation process, to develop special methodological programs.

4. The process of receiving a child in orphanage is not well documented, there are problems with registration and statistical treatment of inmates of orphanages. Throughout Kyrgyzstan, it is necessary to create a database covering the detailed information of every child in orphanages.

5. It is required to improve, upon request, the internal documentation of orphanages, covering regulatory information. Especially concerning the relationship between educators and children from orphanages, open a corner and books for suggestions and complaints.

\section{БИБЛИОГРАФИЧЕСКИЙ СПИСОК}

Крупская Н.К. Педагогические сочинения в 10 т. Т. 6. Дошкольное воспитание. Вопросы семейного воспитания и быта. М.: Изд-во АПН, 1959.

Макаренко А.С. Книга для родителей. М.: Педагогика, 1981.

Назарова И.Б. Возможности и условия адаптации сирот. Социологические исследования, 2001, No. 4, 70-77.

Прихожан А.М. Психология сиротства. СПб.: Питер, 2007.

Петровский А.В., Ярошевский М.Г. (Ред.). Психология: словарь. М.: Политиздат, 1990.

Сатаева Г.А. Подготовка детей-сирот к самостоятельной семейной жизни в условиях детского дома: автореф. дис. ... канд. пед. наук. Казань, 2004.

Салморбекова Р.Б. Основные причины социальной напряженности современной 
семьи: социологический анализ новых жилищных массивов вокруг города Бишкек. В кн: Семья в социокультурном пространстве. СПб., 2011. С. 223-228.

Сухомлинский В.А. О воспитании. М.: Политическая литература, 1982.

Тростанецкая Г. Социальные сироты в нашем обществе. Социальная педагогика, 2004, No. 4, 3-8.

Фурманов И.А. Психологические особенности детей, лишенных родительского попечительства. Минск: Тесей, 1999.

Харчев А.Г. Брак и семья в СССР. М.: Мысль, 1979.

Шульга Т.И. Работа с неблагополучной семьей. М.: Дрофа, 2005.

\section{REFERENCES}

Krupskaya, N.K. (1959). Pedagogicheskie sochineniya v 10 t. T. 6. Doshkol'noe vospitanie. Voprosy semejnogo vospitaniya i byta [Pedagogical works in 10 volumes. Vol. 6. Preschool education. Issues of family education and life]. Moscow: Publisher APN.

Makarenko, A.S. (1981). Kniga dlya roditelej [A book for parents]. Moscow: Pedagogika.

Nazarova, I.B. (2001). Vozmozhnosti i usloviya adaptacii sirot [Possibilities and conditions for the adaptation of orphans]. Sociologicheskie Issledovaniya [Sociological Studies], no. 4, 70-77.

Prihozhan, A.M. (2007). Psihologiya sirotstva [Psychology of Orphanhood]. SPb.: Piter.

Petrovsky, A.V., Yaroshevsky, M.G. (Eds.) (1990). Psihologiya: slovar' [Psychology: Dictionary]. Moscow: Politizdat.

Sataeva, G.A. (2004). Podgotovka detej-sirot $k$ samostoyatel'noj semejnoj zhizni v usloviyah detskogo doma [Preparing orphans for independent family life in an orphanage] ( $\mathrm{PhD}$ Thesis). Kazan'.

Salmorbekova, R.B. (2011). Osnovnye prichiny social'noj napryazhennosti sovremennoj sem'i: sociologicheskij analiz novyh zhilishchnyh massivov vokrug goroda Bishkek [The main causes of social tension of the modern family: a sociological analysis of new housing estates around the city of Bishkek]. In: Sem'ya v sociokul'turnom prostranstve [Family in the sociocultural space] (pp. 223-228). Saint-Petersburg.

Suhomlinskij, V.A. (1982). O vospitanii [About education]. Moscow.: Politicheskaja literatura.

Trostaneckaya, G. (2004). Social'nye siroty v nashem obshchestve [Social orphans in our society]. Social'naya pedagogika [Social pedagogy], no. 4, 3-8.

Furmanov, I.A. (1999). Psihologicheskie osobennosti detej, lishennyh roditel'skogo popechitel'stva [Psychological features of children deprived of parental care]. Minsk: Tesej.

Harchev, A.G. (1979). Brak i sem'ya v SSSR [Marriage and family in the USSR]. Moscow: Mysl'.

Shulga, T.I. (2005). Rabota s neblagopoluchnoj semej [Work with a dysfunctional family]. Moscow: Drofa. 